\title{
Good Samaritanism Versus Citizens' Welfare Rights. A Rejoinder to Alec Pemberton*
}

\section{DIGBY ANDERSON†}

Alec Pemberton's paper 'Rescuing the Good Samaritan: an exposition and a defence of the Samaritan principle in the welfare state' is a welcome attempt to 'rescue' the Good Samaritan and more generally to revive an interest in the ethical imperatives to welfare. It is overdue. While there have been many important criticisms of state welfare over the last 20 years, they have been criticisms of its efficiency or functional desirability on a more or less utilitarian basis. It is indeed time to examine the supposed ethical foundations of state welfare.

Initial thoughts, following the paper's emphasis on Christian injunctions, might include that other revived interest, 'citizenship'. Gospel teaching on welfare is a curious mixture of the universal and the particularistic. The tendency of those who would tie Christianity to socialism is to emphasise the universalistic themes-which certainly exist. Every human is made in the image and after the likeness of God and is therefore of infinite value. The overall Gospel imperative is to preach to and baptise all people and this must involve care for all. The new dispensation overrides boundaries of Jew and Gentile. There is one universal church of 'brotherhood'. The Samaritan parable has its universal theme, of course, in the overriding of race and traditional ties when need beckons. So far so good.

But the parable is not completely universalistic, or rather it is potentially universalistic but in an organic rather than a systematic sense. Its other grand themes are accident and proximity. The moral is to show mercy not to everyone but to anyone whom you happen to encounter, when you encounter them, when need beckons not when the helper chooses. It is wrong to stretch a parable into a theory. But, if it implies a universalism, it would seem to be that all in need will be cared for if each person cares for those immediately about him or her. The image is one of widening circles spontaneously rippling out to cover all. Much discussion can, to be sure, centre on what proximity means: it

- Many of the thoughts in this note were prompted by a reading of Rabbi Jonathan Sacks' paper 'Jews and Christians: the moral concerns we share' in L'Eylah. September, 1988.

$\dagger$ Director, Social Affairs Unit. 


\section{Digby Anderson}

certainly transcends ethnic or national ties as we have seen. No doubt, in an age when electronic media make the distant near, the proximity principle needs much rethinking in its application. But it is certainly there, in the parable, and so is that of accident. Both are in a certain amount of tension with planned state welfare involving equal obligation to all.

Yet other parts of the Gospels and Epistles create yet more tensions. Without seeking in any way to play down the very obvious appeals to ethical universalism, it is also clear that there are many instances of particularism. Christ is explicitly shown loving his mother with an especial love. John is singled out as the beloved disciple, the one whom Jesus loved in some way more than the others. Ethnic boundaries are not obliterated: he loves 'his people' with a special love and feels their rejection with a special sorrow. From the time of what Oscar Cullman calls the Johannine Circle and Raymond Brown, the Community of the Beloved Disciple, there has been recognised an injunction to have a special care for one's fellow religionists, those of the same church, community, monastic order.

Within the command to love all, there is no simple equality of obligation but a network of ties based on proximity, family, religious affiliation. This particularism is affirmed in the priorities given in liturgical and non-liturgical prayer. It is stressed in the theological formulations of 'subsidiarity' and is part of the teachings of that most influential of writers in the post Vatican II era, Cardinal Newman. 'How absurd it is', he declared, 'when writers talk magnificently about loving the whole human race ... The best preparation for loving the world at large ... is to cultivate an intimate friendship and affection towards those immediately about us'. This theme, that we owe more to those near than far, more to family than neighbours, more to neighbours than strangers, and more to individuals than abstractions such as 'mankind' is part of everyone in the street's gut ethics.

It is arguably a more demanding obligation than systematic, egalitarian universalism because it is not content with giving but demands giving and relationships with particular people. Sociologically, it is doubtful whether a society built on systematic universalism would last a day: it is the web of organic obligations which holds society together.

This is, to be sure, a conservative opinion. It is open to those of different opinions to find more or less universalism or particularism in Christianity. But one thing the Gospels do not have much to say about is a certain sort of particularism. It is sure we owe much to all human beings and that we 
owe special consideration to family, neighbours and those we come across, near to us in their need. It is far from clear that we owe much to anyone on the basis of nationhood or citizenship. Modern revivers of citizenship link it firmly to the nation state, that is to welfare rights obligated at national level, the one aggregation which has least warrant in the Gospels. While the Epistles certainly make clear the duties of citizens to 'honour the king' and underwrite a reasonable national identity and patriotism, this is not the case with welfare obligations. The universalism of the Good Samaritan overrides the boundaries of race or nation or even empire. The particularism of proximity in the Good Samaritan and that of family and neighbourhood elsewhere in the Gospels undercut it.

Alec Pemberton is right to query the ethical imperatives of agnostics who advocate welfare. But it is also wrong to assume, as many do assume and without argument, that the welfare state and welfare rights based on citizenship have some privileged warrant from Christianity.

The response to all this might well be to abandon the direct claim to Christian warrant for state welfare and substitute an indirect one along the lines: Christians have a duty to help others and now that we have a nation state, it is the most efficient way of discharging that obligation. This efficiency, of course, is precisely what has been questioned in the last 20 years. Moreover, this weaker utilitarian claim abandons interest in the ethical questions of who is obliged to help whom and under which circumstances. It is no answer.

\section{REFERENCES}

Cardinal Newman (1974), Both Parochial and Plain Sermons II. cited in C.S. Dessain. The Mind of Cardinal Newman. Catholic Truth Society, London. 